\title{
Toward understanding, managing, and protecting microbial ecosystems
}

\author{
Paul L. E. Bodelier* \\ Department of Microbial Ecology, Netherlands Institute of Ecology, Wageningen, Netherlands
}

\section{Edited by:}

Jeanette M. Norton, Utah State

University, USA

Reviewed by:

Nico Boon, Ghent University, Belgium

Angela Kent, University of Illinois at

Urbana-Champaign, USA

${ }^{*}$ Correspondence:

Paul L. E. Bodelier, Department of

Microbial Ecology, Netherlands

Institute of Ecology (NIOO - KNAW),

Droevendaalsesteeg 10, NL-6708 PB

Wageningen, Netherlands.

e-mail:p.bodelier@nioo.knaw.nl
Microbial communities are at the very basis of life on earth, catalyzing biogeochemical reactions driving global nutrient cycles. However, unlike for plants and animals, microbial diversity is not on the biodiversity-conservation agenda. The latter, however, would imply that microbial diversity is not under any threat by anthropogenic disturbance or climate change. This maybe a misconception caused by the rudimentary knowledge we have concerning microbial diversity and its role in ecosystem functioning. This perspective paper identifies major areas with knowledge gaps within the field of environmental microbiology that preclude a comprehension of microbial ecosystems on the level we have for plants and animals. Opportunities and challenges are pointed out to open the microbial black box and to go from descriptive to predictive microbial ecology.

Keywords: microbial diversity, biodiversity-ecosystem functioning, resistance, resilience, redundancy

\section{MICROBIAL DIVERSITY AND CONSERVATION?}

Ecosystems collectively determine biogeochemical processes that regulate the Earth System. Loss of biodiversity is generally regarded as detrimental to ecosystems and ecosystem functioning and therefore has been a central issue for environmental scientists during the last decades (Hooper et al., 2005; Balvanera et al., 2006; Cardinale et al., 2006). Microorganisms (i.e., bacteria, archaea, protozoa, and fungi) comprise a major part of the total biomass of organisms inhabiting on earth (Whitman et al., 1998) and represent the largest source of biodiversity (Gans et al., 2005; Sogin et al., 2006; Rusch et al., 2007). They play critical roles in natural biogeochemical processes, sustaining ecosystem functioning (Falkowski et al., 2008). Many of the reactions catalyzed by microorganisms are fundamental to functioning of engineered or managed systems like wastewater treatment plants, agricultural fields, and industrial bioreactors providing many services to our societies (see Table 1). Considering the challenges we are facing with overexploitation of the planet, climate change, pandemics, increasing demands in food production, need for renewable energy and resources (Verstraete et al., 2007), it is remarkable that microbes and their diversity are absent in the ongoing debates about global biodiversity loss and conservations policy, despite various pleas to do so (Colwell, 1997; Cockell, 2005; Cockell and Jones, 2009; Sutherland et al., 2010). The biodiversity-ecosystem function (BEF) research inherently requires the investigation of the relationship between species-assemblies and ecosystem processes. High diversity, rapid generation times, high adaptability due to genome rearrangements, and ubiquitous distribution, have led to the notion that microbial communities are highly redundant and omnipresent and therefore inextinguishable. However, the latter may be a misconception driven by a number of gaps in our assessment and understanding of the functioning of microbial communities and the relevance of microbial diversity in ecosystem functioning being (i) inadequate diversity assessment, (ii) no clear biogeographical patterns, (iii) inability to link diversity to function, (iv) lack of knowledge on functional redundancy, resistance, and resilience of microbial communities.

\section{INADEQUATE MICROBIAL DIVERSITY ASSESSMENT}

Diversity of plant and animal communities is traditionally assessed by counting taxonomically described species and calculating diversity indices composed of richness (i.e., number of species) and evenness (relative abundance of species). This approach is also the routine way to assess microbial diversity despite the fact that there are some fundamental discrepancies between macrobial and microbial ecology in the way to define taxonomic units. The first problem is that approx. only $1 \%$ of the actual microbial biodiversity is represented as cultured organisms while the characteristics and functions of the remaining $99 \%$ are unknown. There are only 7000 microbial species (Achtman and Wagner, 2008) described geno- as well as phenotypically whereas DNA based-methods have identified more than 100 prokaryotic phyla to be present in ecosystems (Alain and Querellou, 2009; Pace, 2009). Ribosomal RNA sequence divergence and DNA-DNA hybridization (DDH) are the main classifiers of microbial taxonomy where less than $70 \% \mathrm{DDH}$ and less than $98.7 \%$ similarity of the $16 \mathrm{~s}$ rRNA demarcates microbes to belong to different species (Schleifer, 2009). These thresholds are congruent with $95 \%$ average nucleotide identity on the whole genome level (Konstantinidis and Tiedje, 2005; Raes and Bork, 2008; Wilmes and Bond, 2009).

However, below the species level the sequence-identity cut-off value used to demarcate species have led to "species" that are still enormously diverse in their genome content, physiology, and ecology (Staley, 2006). Hence, the application of richness and evenness, based on these taxonomic criteria will not be very helpful in studying BEF relationships in microbial communities because there is no direct link between these units and the functions catalyzed by the community. For example, soil contains up to $10^{6}$ bacterial 
Table 1 | Major groups of microbes and ecosystem services they provide.

\begin{tabular}{|c|c|c|c|}
\hline Microbial group & Process & Ecosystem service & Ecosystem service category \\
\hline $\begin{array}{l}\text { Heterotrophic bacteria/ } \\
\text { archaea }\end{array}$ & $\begin{array}{l}\text { Organic matter breakdown, } \\
\text { mineralization }\end{array}$ & $\begin{array}{l}\text { Decomposition, nutrient recycling, climate } \\
\text { regulation, water purification }\end{array}$ & Supporting and regulating \\
\hline Photoautotrophic bacteria & Photosynthesis & Primary production, carbon sequestration & Supporting and regulating \\
\hline Chemo(litho)autotrophic & $\begin{array}{l}\text { Specific elemental transformations } \\
\text { (e.g., } \mathrm{NH}_{4}^{+}, \mathrm{S}_{2}^{-}, \mathrm{Fe}_{2}^{+}, \mathrm{CH}_{4} \text { oxidation) }\end{array}$ & $\begin{array}{l}\text { Nutrient recycling, climate regulation, water } \\
\text { purification }\end{array}$ & Supporting and regulating \\
\hline Unicellular phytoplankton & Photosynthesis & Primary production, carbon sequestration & Supporting and regulating \\
\hline Archaea & $\begin{array}{l}\text { Specific elemental transformation (e.g., } \\
\text { metals, } \mathrm{CH}_{4} \text { formation, } \mathrm{NH}_{4}^{+} \text {oxidation), } \\
\text { often in extreme habitats. }\end{array}$ & $\begin{array}{l}\text { Nutrient recycling, climate regulation, carbon } \\
\text { sequestration }\end{array}$ & Supporting and regulating \\
\hline Protozoa & Mineralization of other microbes & Decomposition, nutrient recycling, soil formation & Supporting \\
\hline Fungi & $\begin{array}{l}\text { Organic matter breakdown and } \\
\text { mineralization }\end{array}$ & $\begin{array}{l}\text { Decomposition, nutrient recycling, soil formation, } \\
\text { primary production (i.e., mycorrhizal fungi) }\end{array}$ & Supporting \\
\hline Viruses & Lysis of hosts & Nutrient recycling & Supporting \\
\hline All & $\begin{array}{l}\text { Production of metabolites (e.g., } \\
\text { antibiotics, polymers), degradation of } \\
\text { xenobiotics, genetic transformation, } \\
\text { and rearrangement }\end{array}$ & $\begin{array}{l}\text { Production of precursors to industrial and } \\
\text { pharmaceutical products }\end{array}$ & Provisional \\
\hline All & $\begin{array}{l}\text { Huge diversity, versatility, } \\
\text { environmental and biotechnological } \\
\text { applications }\end{array}$ & $\begin{array}{l}\text { Educational purposes, getting students interested } \\
\text { in science }\end{array}$ & Cultural \\
\hline
\end{tabular}

The last column depicts the ecosystem service category as was defined in the Millennium Ecosystem Assessment (2005). Modified from Ducklow, 2008.

genotypes $\mathrm{g}^{-1} \mathrm{DW}$ (Gans et al., 2005), but the phylotypic diversity estimates are one order of magnitude lower (Roesch et al., 2007). It has been demonstrated recently, that environmental parameters effect (e.g., pH, cattle grazing) microbial communities at taxonomic levels higher than species, hence, indicating a degree of ecological coherence at these higher taxonomic levels. (Lauber et al., 2009; Philippot et al., 2010). However, these relationships are at the level of factors determining the distribution but do not tell anything about the functions catalyzed by these ecological coherent groups and the consequences for ecosystem functioning.

Hence, approaching the BEF question in a meaningful way in microbial communities requires an approach beyond the classical richness and evenness approach of arbitrarily demarcated taxonomic units. There is a need for novel concepts in microbial BEF research regarding ecological relevant units for microbes to by-pass the species hang-up in order to develop generic concepts and theories in microbial ecology. This required paradigm shift away from taxa oriented concepts of community analysis toward functional biodiversity is also starting to be developed for microbial communities. Genomic and proteomic techniques enable high-throughput inventories of microbial functional units (protein coding genes, enzymes, metabolites) which can be regarded as microbial traits being the key components of the overall ecosystem (Green et al., 2008).

\section{MICROBIAL BIOGEOGRAPHY}

The conventional view of microbial distribution of species through space and time has been dominated for decades by the "BaasBecking” hypothesis (see de Wit and Bouvier, 2006) "everything is everywhere, but the environment selects." The lack of dispersal limitations of microorganisms would ensure a global distribution, but that local deterministic factors would determine the relative abundance of "latent" and "flourishing" species. This view is in sharp contrast with plants and animals which show clear taxa-area relationships and biogeography. The Baas-Becking legacy is likely the main reason why microbial diversity is not on the biodiversityconservation agenda. However, the last decade there are a number of studies demonstrating species-area relationships, biogeography, and spatial patterns at various scales for microbes (HornerDevine et al., 2004; Bell et al., 2005a; Fierer and Jackson, 2006) and more recently even using a functional gene-based approach (Zhou et al., 2008). Next to this, microbial endemism has been reported as well (Cho and Tiedje, 2000; Pommier et al., 2007). Using high-throughput sequencing technology a number of studies clearly demonstrated the presence of habitat specific communities shaped by edaphic factors and historical contingencies (Fierer et al., 2007; von Mering et al., 2007; Lauber et al., 2009). A meta analysis of all currently available $16 \mathrm{~S}$ rRNA gene sequences revealed clear environmental distributions on the genus or species level with soil and freshwater as least selective habitats while marine, animal, and thermal habitats were most selective (Tamames et al., 2010). Similarly, a meta analysis of all currently available denitrification genes showed that similarities between globally distributed communities corresponded to similarities in habitat salinity and the majority of communities were phylogenetically clustered more than expected by chance, indicating habitat filtering (Jones and Hallin, 2010). 


\section{LINKING FUNCTION TO IDENTITY}

Assessing BEF relationships in the classical macro-ecological context would require the connecting of individual microbial species to the biogeochemical processes they catalyze. However, considering the problems in defining relevant ecological units, the metabolic versatility, the large number of unknown species, and the scale issue involved, this is the central problem in the field of environmental microbiology. The majority of studies in the literature have relied on correlating changes in activity to changes in community composition or diversity, and only a few articles can actually show a causal relationship. A myriad of techniques have been developed for linking diversity and function (see Wagner, 2009). However, many of these techniques were based on the analyses of ribosomal RNA or mRNA transcripts of functional genes, indicating only the potential to be involved in specific processes. The use of stable isotope probing (SIP) has evoked a major breakthrough in environmental microbiology (see Chen and Murrell, 2010). Stable isotopes $\left({ }^{13} \mathrm{C} /{ }^{15} \mathrm{~N}\right)$ are incorporated following assimilation of a specific substrate into taxonomically relevant molecules [RNA/DNA (Whiteley et al., 2006; Rasche et al., 2009); PLFA; phospholipids, see (Bodelier et al., 2009b) or proteins (Jehmlich et al., 2009)]. Only the microbes which have actively been incorporating the stable isotopes are detected when analyzing RNA/DNA, after density centrifugation, or PLFA using GC-IRMS or proteins using GC-MS or LC-MS. The major disadvantage of SIP is the use of unnaturally high substrate concentrations, the different label uptake rates per species, and cross feeding. Recent work brought improvements in the shortcomings of traditional SIP studies. By combining SIP with magnetic bead capturing of mRNA (Miyatake et al., 2009), Raman spectroscopy, NanoSIMS (Secondary Ion Beam Mass Spectroscopy; Wagner, 2009) and metagenomics, active species of which no cultured representatives are available or unknown pathways or genes involved in biogeochemical processes were detected, avoiding high substrate concentrations and long-incubation times (see Chen and Murrell, 2010). The challenge in applying SIP-based techniques will be in BEF experiments, where experimental designs allowing for causal and mechanistic conclusions require high sample throughput.

\section{FUNCTIONAL REDUNDANCY, RESISTANCE, AND RESILIENCE IN MICROBIAL ECOSYSTEMS}

Another paradigm that led to the absence of microbial diversity in BEF debate, conservation issues, and global biogeochemical process models is the idea of microbial omnipresence, high adaptability, and functional redundancy. Hence, many species carrying the same function ensures stability of the process when species are lost or temporarily inactive. But is this the rule or are the current methods and approaches used studying redundancy, resistance, and resilience inadequate to answers these questions? Well, the latter is definitely a part of the story. Functional redundancy sensu stricto is difficult to assess in microbial communities, since it requires the contribution of individual community members to processes and separation between diversity and environmental factors, which is a difficult task as outlined in the previous sections. Another part of the story probably lies in natural complexity, making generalizations regarding redundancy using the current approaches rather useless. This becomes apparent in recent overviews and meta-analyses on
BEF in microbial communities were equal numbers of studies are found that report on positive, negative, or inconclusive responses of increased diversity on ecosystem processes (Ducklow, 2008). Recently, a comprehensive meta-analyses demonstrated that out of 110 studies more than $70 \%$ demonstrate that microbial community composition was not resistant (i.e., the degree to which community composition remains unchanged when disturbed) against disturbances (fertilization; $\mathrm{CO}_{2}$ increase; temperature; carbon amendment; Allison and Martiny, 2008). This held true for broad taxonomic groups (fungi, bacteria, archaea) as well as narrow functional guilds catalyzing specific functions (e.g., methane oxidation, nitrification). The same study demonstrated that the resilience (i.e., the rate at which microbial community composition returns to its original composition after being disturbed) can be in the order of years. An example is the suppression of atmospheric methane consumption in soils by nitrogenous fertilizers which can last for decades after fertilizer application has ceased because there no other microbes to take over (see Bodelier and Laanbroek, 2004). The latter example represents functional guilds which catalyze a specific function and which do not harbor many species and, hence, are less redundant (e.g., methane production and oxidation, ammonia oxidation). Similar "vulnerability "one would expect in symbiotic relationship (e.g., mycorrhiza, $\mathrm{N}_{2}$ fixers) where it has been shown that reduced diversity has led to lower biomass production of the host-plants (see van der Heijden et al., 2008) indicating that species cannot be replaced without consequences for ecosystem functioning. Considering this it is tempting to focus on these narrow functional guilds and these specific symbiont-host relationships when thinking about vulnerable microbial communities. However, quite some studies have demonstrated a direct relationship between diversity and ecosystem process rate for general broad functions, like respiration or denitrification (Setala and McLean, 2004; Wohl et al., 2004; Balser and Firestone, 2005; Bell et al., 2005b; Salles et al., 2009). Hence, reducing the diversity also for these broad range, presumably redundant functions will have consequences for ecosystem functioning. By growing plants on soils inoculated with a microbial community of reduced diversity it was demonstrated that plant biomass, being the outcome of many interacting processes, was reduced (Hol et al., 2010). The absence of "rare" microbes led to higher nutrient content of the plants and made them more susceptible to pest organisms. These indirect ecosystem effects due to reduced microbial diversity will often go unnoticed when only measuring direct connections between diversity and single function catalyzed by the microbes, as has been done most frequently.

The degree of redundancy can also depend very much on the environmental conditions. Under nutrient poor conditions many species may not perform well leading to diversity effects on ecosystem functions which are not detected under optimal conditions (see van der Heijden et al., 2008). Also heavy perturbations of environments with chemicals or heavy metals may lead to such a situation of lowered redundancy (Gans et al., 2005).

The strong focus on species richness, being synonymous for redundancy can also impair our understanding of BEF in microbial communities. Recovery of denitrification after salt stress in laboratory microcosms strongly depended on the initial evenness of the community (Wittebolle et al., 2009). The relative abundance of species before perturbation was of greater importance than the 
number of species present, all capable of performing denitrification. Hence, even when an ecosystem function is supported by a highly redundant community, the resilience against disturbance can be low when the relative abundance is very uneven. This may be caused by non-resistant dominant community members or density dependent mutualism between species, like was shown for the process of nitrification (Graham et al., 2007) or syntrophic consortia (Kato and Watanabe, 2010).

Maybe one of the most important gaps in our understanding and assessment of redundancy and the BEF in microbial communities is the focus on diversity in relation to one particular, isolated function. However, overall ecosystem functioning is the collective action of many species carrying out various functions, often in interaction. It was shown for a number of datasets that diversity is more important for multifunctionality than it is for single functions (Gamfeldt et al., 2008). Hence, species can contribute to more than one function which introduces another level of redundancy. Hence, when looking at overall ecosystem functions (e.g.) primary productivity) it will always take more species than the number of single functions contributing to overall ecosystem function due to the fact that not all species can perform all functions. The latter was also demonstrated for microbial systems where a number of soil functions were measured and the most parsimonious set of species (OTU's on DGGE) was determined which positively influenced these functions (He et al., 2009). By backward-elimination boosted tree analyses it was shown that reducing microbial diversity will eventually lead to loss of function. The positive relationship between diversity and ecosystem-multifunctionality has been explained by complementarity between species, positive selection, or niche differentiation (Loreau and Hector, 2001; Cardinale et al., 2006; Salles et al., 2009). Hence, for overall ecosystem functioning but also for the performance of single functions multiple traits of species have to be taking into account. It is the overall geno- plus phenotype of a microbe which makes it survive or function in a particular habitat.

Another aspect we have to consider in the classical view on microbial communities being functionally highly redundant is the scale issue. Populations or communities of interacting microbes on microbial relevant scales may not consist of many different species due to spatial arrangement or isolation, e.g., along roots, soil pores, plant leaves, biofilms, or microbial flocs in sewage treatment (Lindow and Leveau, 2002; Daims et al., 2006; Battin et al., 2007; Gross et al., 2010). Hence, for example at the soil aggregate scale the number of species present may be very low as will also be redundancy. Whether the role of diversity for microbial ecosystem functioning on the landscape scale is a simple addition of what happens on the micro scale is one of the biggest challenges in microbial BEF research. Nevertheless, it is evident that in heterogeneous, spatially separated micro-habitats colonized by low numbers of cells, functional redundancy is an irrelevant concept.

The growing body of experimental evidence suggest that microbial communities can be sensitive to disturbances and that resilience is linked to diversity. Next to this, functional redundancy is certainly not a general characteristic of microbial communities. However, the issues put forward in the preceding paragraphs preclude firm conclusions regarding sensitivity and vulnerability of microbial communities and what the role of community composition is in this matter. When thinking about conservation, a fundamental problem is that the great majority of microbial diversity is unknown in terms of species identity and associated functional characteristics. Hence, we do not know what to conserve but we also do not know what we have lost.

\section{FROM DESCRIPTIVE TO PREDICTIVE; TOWARD UNDERSTANDING AND PROTECTION FROM SPECIES RICHNESS TO FUNCTIONAL BIODIVERSITY}

It is obvious that the omission of microbial communities in management and conservation of ecosystems is due to a lack of understanding of the functioning and composition of environmental microbial communities leading to the assumption that microbial communities are insensitive, resilient, and redundant. However, getting microbial diversity under the attention of policy and management will require incorporation of microbial diversity into predictive ecosystem process models.

However, this will require a different approach as has been followed till now. Evidently, using richness of taxonomically described species is not the way to follow in microbial BEF research. In parallel to plant-sciences (McGill et al., 2006), a functional biodiversity approach using species, genus, or community functional traits would make much more sense as a framework to be used in microbial BEF research, especially, considering the swapping of genes across microbial taxonomic units (McDaniel et al., 2010). Descriptions of such trait-centered approaches for microbial communities have already been initiated (Allison and Martiny, 2008; Green et al., 2008) awaiting testing and application.

Based on the functional trait approach Allison and Martiny (2008) proposed a conceptual model that incorporates microbial diversity via functional traits into a process model. This model assumes a number of taxa in a functional group. The community process rate is the sum of the products of the abundances and the biomass-specific physiological process rate of all taxa. To predict community response to environmental disturbance, taxa specific physiological response rates to disturbance were introduced which principally have to be determined for every individual taxon. However, the model assumes that functional traits and physiological responses are related to phylogeny and hence can be estimated from phylogenetic information. This would result in aggregating taxa which have similar traits and responses in this model. The challenge remains, however, to establish basic relationships between traits, responses, and phylogeny. This could be achieved using artificial communities of microbes in which abundance and individual physiological responses can be measured for every single taxon in these communities. Methane oxidizing proteobacteria would be an ideal functional group to test this model considering the methodological possibilities to link their function to their phylogeny (Bodelier et al., 2009a,b). A project testing the Allison and Martiny (2008) model using methanotrophs is under way ${ }^{1}$.

A helpful tool to facilitate the aggregation of phylogenetic groups with common traits may the "ecotype" systematics, where evolutionary and ecological information demarcates groups of organism that have a history of coexistence as distinct lineages and a prognosis of future coexistence, leading to units of bacterial

${ }^{1}$ http://www.mecomecon.org/ 
ecology and evolution below the conventional species level-cut-off (Koeppel et al., 2008). This approach may point out phylogenetic units putatively sharing a common eco-physiology, even when no cultured representatives are available, thereby focusing microbial $\mathrm{BEF}$ research.

The functional biodiversity approach would also offer the incorporation of interactions multifunctionality and diversity effects across trophic levels, as been proposed recently (de Bello et al., 2010). These authors propose the concept of "trait-ecosystem service clusters" as traits of various organisms that together influence ecosystem services over trophic levels. Ultimately this will be the goal to understand the role of microbial diversity as an integral part of ecosystems. Using gene-expression as analogs of microbial traits, microbial functional molecular ecological networks can be established using functional microarrays (GeoChip) and subsequent statistical analyses to find highly correlated clusters of genes (Zhou et al., 2010) as response to environmental change or perturbation. The identified clusters of genes, designated as ecological network modules, can be linked to ecosystem processes or properties and would fit as such in the trait-service cluster concept. High-throughput genomic and proteomic techniques offer the potential to monitor genes, transcripts, and proteins of microbial communities in spatial as well as temporal high resolution and thereby identify correlated microbial functional traits. However, to use these relationships in microbial BEF studies we have to know what the biology is underlying these correlations and whether they can be used as ecosystem process proxies, possibly linked to phylogenetic categories. This information still has to be retrieved from culture or single cell studies.

\section{SINGLE CELL AND COMMUNITY ECO-PHYSIOLOGY}

Besides obtaining empirical results demonstrating biodiversityfunction relationships for microbial communities, it will be inevitable to understand the mechanistic basis for these observations. These mechanisms are to be found at the cellular level and in the interaction between cells, communities with the environment, and higher trophic levels. However, in microbial BEF these levels of organization have largely been treated as "black boxes" combined with being largely of descriptive nature and disconnected to ecological concepts. Approaches in microbial BEF have been primarily "Top-down" manipulating the "black box" and measuring the effect on singular ecosystem processes (see Figure 1). However, understanding the structure and functioning of microbial communities at the cell and community level, is necessary to understand mechanisms and to generate the knowledge needed to move toward predictions on ecosystem process level. The rapid methodological developments of the last decades are narrowing down the limitations which kept the discipline at the descriptive level. The "omics" techniques enable studying community ecology as well as physiology (Konopka, 2009) of known as well as unknown microbial species. The genome of single microbial cells derived directly from the environment can be sequenced (Woyke et al., 2010) and physiological responses can be recorded (Musat et al., 2008; Konopka et al., 2011). Moreover, in situ adaptation of community members (Denef et al., 2009; Belnap et al., 2010) or in situ profiling of whole genome transcripts and proteins of individual species (Kalyuzhnaya et al., 2010) is feasible. Methodology and concepts are emerging enabling individual-based physiology and ecology (Leveau, 2009; Wagner, 2009; Gross et al., 2010) and even interactions on microbial relevant scale (Kim et al., 2008). Theoretical and conceptual approaches from macro ecology are being applied to understand microbial community structure and to link it to ecosystem processes (Prosser et al., 2007; Allison and Martiny, 2008; Green et al., 2008; Salles et al., 2009). These novel avenues at the level of environmental molecules, cells, and communities will lead us to causal mechanistic understanding of environmental microbial communities, eventually leading to the opening of the "Black box" (see Figure 1). It will take the field of environmental microbiology a step closer toward moving from descriptive to predictive.

\section{TOWARD CONSERVATION AND MANAGEMENT}

Preservation and management of our ecosystems and ecosystem services has the highest research priority globally (Millennium Ecosystem Assessment, 2005). Biodiversity is a crucial component in preservation of ecosystem services globally and there are many coordinated activities to preserve biodiversity and habitats. In the previous sections it became evident that it is not a matter of a lack

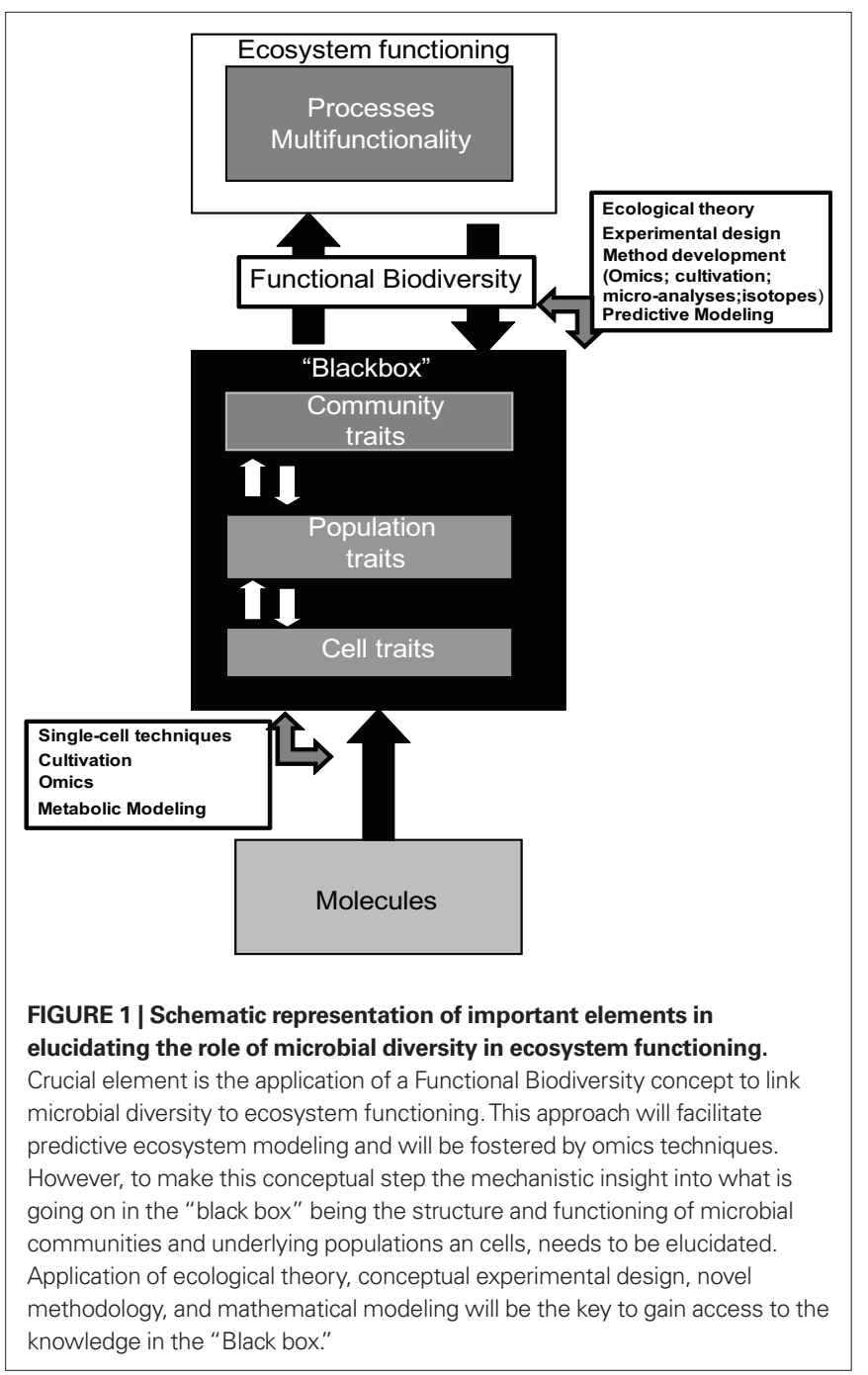


of vulnerability but mainly a lack of understanding of microbial ecosystems, which causes the absence of microbial diversity from conservation initiatives. I would say that the lack of knowledge in combination with the crucial services they provide would be the best argument for the protection of microbial diversity and ecosystems. However, for the time being it seems that we have to take the level of knowledge on microbial communities to the same level we have with plants and animals, as outlined in the previous sections, before microbial diversity will be taken seriously in conservation policy. However, this will require multidisciplinarity and input from various scientific disciplines (microbiology, genetics, genomics, ecology, physics, engineering, chemistry, mathematical modeling; biogeochemistry, theoretical biology, systems biology). It will also require the coordinated application of novel technologies embedded in well-designed ecological experimentation that will allow for causal and mechanistic information to emerge. This will also include long-term experiments (Eisenhauer et al., 2010) which are not common in microbial BEF research. Research consortia are needed to channel the explosive developments toward microbial ecological studies and subjects. Achieving this will require intense cooperation and exchange of researchers between scientific disciplines and intense training efforts to educate the researchers which will work in this multidisciplinary field. This cross fertilization between "omics" techniques and experimental microbial ecology is the first step to reach an ecosystem biology approach, incorporating microbial diversity into ecosystem process models. However, we are not yet there. What to do in the mean time. Recently, a "roadmap" toward microbial conservation has been put forward (Cockell and Jones, 2009). Important elements in this plea were habitat conservation, legislation, education, and ethical considerations. Since habitat conservation is already integrated in the EU-legislation ${ }^{2}$ it would be most efficient to consider taking habitat characteristics into account which are important for microbial communities. In the EU-Soil Framework Directive ${ }^{3}$ in development, microbes are at least mentioned and taking into consideration (Gardi et al., 2009). Great efforts are under way to make inventories of soil microbial diversity using metagenomics techniques, attempting to catalog what is out there, including associated metadata (Costello et al., 2006; Gardi et al., 2009; Ranjard et al., 2010). A recently started initiative is aiming at sequencing many relevant microbiomes distributed over the globe $e^{4}$. Mining of these data and associated

${ }^{2} \mathrm{http}$ ///ec.europa.eu/environment/nature/index_en.htm

${ }^{3}$ http://ec.europa.eu/environment/soil/biodiversity.htm

${ }^{4}$ http://www.earthmicrobiome.org/

\section{REFERENCES}

Achtman, M., and Wagner, M. (2008). Microbial diversity and the genetic nature of microbial species. Nat. Rev. Microbiol. 6, 431-440.

Alain, K., and Querellou, J. (2009). Cultivating the uncultured: limits, advances and future challenges. Extremophiles 13, 583-594.

Allison, S. D., and Martiny, J. B. H. (2008). Resistance, resilience, and redundancy in microbial communities. Proc. Natl. Acad. Sci. U.S.A. 105, 11512-11519.

environmental metadata will yield relationships between microbial diversity and important environmental characteristics which can be used in guidelines for habitat preservation in conservation policy. It will also facilitate the establishment of so called "normal operating ranges" for microbial habitats, indicating what the level of microbial diversity and functioning is to be expected in for example "normally" functioning soils. Deviations from this "normal operating range" may be interpreted as disturbances of the soils under investigation. Such an exercise has been carried out in a very intensive soil monitoring network in the Netherlands which included 300 soil sampling sites covering various land-use types and soil types. Monitoring complete foodwebs in these sites for 6 years identified most important life-support functions in these soils including the abundance and diversity of the associated biota. This database led to guidelines for the range of diversity and numbers of organisms that should be present in a specific soil type in order to function normally (Rutgers et al., 2009).

Hence, the policy mindset is going in the right direction, theoretical frameworks are in place, and methodology is developing in a way that in the near future global biodiversity-conservation will embrace all three domains of life on our planet. The incorporation of functional microbial traits into predictive ecosystem models will also facilitate the management of habitats taking environmental effects on microbes into account. Large scale sequencing efforts will provide information on what microbes are out there in our ecosystems. Clever, conceptually, and theoretical supported experimentation will reveal what these microbes are capable of increasing the appreciation for this supporting and regulating domain of life promoting its conservation.

\section{ACKNOWLEDGMENTS}

The basis of paper was part of the outcome of the workshop "EuroMicrobe"; exploring the rationale for conservation of environmental microbial communities and associated habitats, held from December 8-10, 2009, Hilversum, the Netherlands. This workshop was part of the ESF EUROCORE Eurodiversity (ERAS-CT-2003-98049, 6th EU-framework programme). This work was also part of the European Science Foundation EUROCORES Programme EuroEEFG as supported by funds from the Netherlands Organisation for Scientific Research (NWO). The author wants to thank Prof. Nico Boon, Dr. Holger Daims, Dr. Ciro Gardi, Dr. Sara Hallin, Dr. Graeme Nicol, Dr. Jakob Pernthaler, Dr. Joana Salles, Prof. Michael Schloter for their constructive comments to the contents of this manuscript. This publication is publication no. 5024 of the Netherlands Institute of Ecology.

Battin, T. J., Sloan, W. T., Kjelleberg, S., Daims, H., Head, I. M., Curtis, T. P., and Eberl, L. (2007). Microbial landscapes: new paths to biofilm research. Nat. Rev. Microbiol. 5, 76-81.

Bell, T., Ager, D., Song, J. I., Newman, J. A., Thompson, I. P., Lilley, A. K., and van der Gast, C. J. (2005a). Larger islands house more bacterial taxa. Science 308, 1884-1884.

Bell, T., Newman, J. A., Silverman, B. W., Turner, S. L., and Lilley, A. K. (2005b). The contribution of species richness and composition to bacterial services. Nature 436, 1157-1160.

Belnap, C. P., Pan, C., VerBerkmoes, N. C., Power, M. E., Samatova, N. F., Carver, R. L., Hettich, R. L., and Banfield, J. F. (2010). Cultivation and quantitative proteomic analyses of acidophilic microbial communities. ISME J. 4, 520-530.

Bodelier, P. L. E., Bar-Gillisen, M.-J., Hordijk, K., Damsté, J. S., Rijpstra, W. I., Geenevasen, J.A., and Dunfield, P.F. (2009a). A reanalysis of phospholipid 
fatty acids as ecological biomarkers for methanotrophic bacteria. ISME J. 3, 606-617.

Bodelier, P. L. E., Kamst, M., MeimaFranke, M., Stralis-Pavese, N., and Bodrossy, L. (2009b). Wholecommunity genome amplification (WCGA) leads to compositional bias in methane-oxidizing communities as assessed by pmoA-based microarray and QPCR. Environ. Microbiol. Rep. 1, 434-441.

Bodelier, P. L. E., and Laanbroek, H. J. (2004). Nitrogen as a regulatory factor of methane oxidation in soils and sediments. FEMS Microbiol. Ecol. 47, 265-277.

Cardinale, B. J., Srivastava, D. S., Duffy, J. E., Wright, J. P., Downing, A. L., Sankaran, M., and Jouseau, C. (2006). Effects of biodiversity on the functioning of trophic groups and ecosystems. Nature 443, 989-992.

Chen, Y., and Murrell, J. C. (2010). When metagenomics meets stable-isotope probing: progress and perspectives. Trends Microbiol. 18, 157-163.

Cho, J. C., and Tiedje, J. M. (2000). Biogeography and degree of endemicity of fluorescent Pseudomonas strains in soil. Appl. Environ. Microbiol. 66, 5448-5456.

Cockell, C. S. (2005). The value of microorganisms. Environ. Ethics 27, 375-390.

Cockell, C. S., and Jones, H. L. (2009). Advancing the case for microbial conservation. Oryx 43, 520-526.

Colwell, R. R. (1997). Microbial diversity: the importance of exploration and conservation. J. Ind. Microbiol. Biotechnol. 18, 302-307.

Costello, M. J., Bouchet, P., Emblow, C. S., and Legakis, A. (2006). European marine biodiversity inventory and taxonomic resources: state of the art and gaps in knowledge. Mar. Ecol. Prog. Ser. 316, 257-268.

Daims, H., Lucker, S., and Wagner, M. (2006). Daime, a novel image analysis program for microbial ecology and biofilm research. Environ. Microbiol. 8, 200-213.

de Bello, F., Lavorel, S., Diaz, S., Harrington, R., Cornelissen, J. H. C., Bardgett, R. D., Berg, M. P., Cipriotti, P., Feld, C. K., Hering, D., da Silva, P. M., Potts, S. G., Sandin, L., Sousa, J. P., Storkey, J., Wardle, D. A., and Harrison, P. A. (2010). Towards an assessment of multiple ecosystem processes and services via functional traits. Biodivers. Conserv. 19, 2873-2893.

de Wit, R., and Bouvier, T. (2006). "Everything is everywhere, but, the environment selects"; what did Baas Becking and Beijerinck really say? Environ. Microbiol. 8, 755-758.
Denef, V. J., VerBerkmoes, N. C., Shah, M. B., Abraham, P., Lefsrud, M., Hettich, R. L., and Banfield, J. F. (2009). Proteomics-inferred genome typing (PIGT) demonstrates inter-population recombination as a strategy for environmental adaptation. Environ. Microbiol. 11, 313-325.

Ducklow, H. (2008). Microbial services: challenges for microbial ecologists in a changing world. Aquat. Microb. Ecol. 53, 13-19.

Eisenhauer, N., Bessler, H., Engels, C., Gleixner, G., Habekost, M., Milcu, A., Partsch, S., Sabais, A. C. W., Scherber, C., Steinbeiss, S., Weigelt, A., Weisser, W. W., and Scheu, S. (2010). Plant diversity effects on soil microorganisms support the singular hypothesis. Ecology 91, 485-496.

Falkowski, P. G., Fenchel, T., and Delong, E. F. (2008). The microbial engines that drive earth's biogeochemical cycles. Science 320, 1034-1039.

Fierer, N., and Jackson, R. B. (2006). The diversity and biogeography of soil bacterial communities. Proc. Natl. Acad. Sci. U.S.A. 103, 626-631.

Fierer, N., Morse, J. L., Berthrong, S. T., Bernhardt, E. S., and Jackson, R. B. (2007). Environmental controls on the landscape-scale biogeography of stream bacterial communities. Ecology $88,2162-2173$.

Gamfeldt, L., Hillebrand, H., and Jonsson, P. R. (2008). Multiple functions increase the importance of biodiversity for overall ecosystem functioning. Ecology 89, 1223-1231.

Gans, J., Wolinsky, M., and Dunbar, J. (2005). Computational improvements reveal great bacterial diversity and high metal toxicity in soil. Science 309, 1387-1390.

Gardi, C., Montanarella, L., Arrouays, D., Bispo, A., Lemanceau, P., Jolivet, C., Mulder, C., Ranjard, L., Rombke, J., Rutgers, M., and Menta, C. (2009). Soil biodiversity monitoring in Europe: ongoing activities and challenges. Eur. J. Soil Sci. 60, 807-819.

Graham, D. W., Knapp, C. W., Van Vleck, E. S., Bloor, K., Lane, T. B., and Graham, C. E. (2007). Experimental demonstration of chaotic instability in biological nitrification. ISME J. 1 , 385-393.

Green, J. L., Bohannan, B. J. M., and Whitaker, R. J. (2008). Microbial biogeography: from taxonomy to traits. Science 320, 1039-1043.

Gross, C. A., Reddy, C. K., and Dazzo, F. B. (2010). CMEIAS color segmentation: an improved computing technology to process color images for quantitative microbial ecology studies at single-cell resolution. Microb. Ecol. 59, 400-414.

He, J.Z., Ge, Y., Xu, Z. H., and Chen, C. R. (2009). Linking soil bacterial diversity to ecosystem multifunctionality using backward-elimination boosted trees analysis. J. Soils Sediments 9, 547-554

Hol,W.H.G., de Boer,W., Termorshuizen, A. J., Meyer, K. M., Schneider, J. H. M., van Dam, N. M., van Veen, J. A. and van der Putten, W. H. (2010). Reduction of rare soil microbes modifies plant-herbivore interactions. Ecol. Lett. 13, 292-301.

Hooper, D. U., Chapin, F. S., Ewel, J. J., Hector, A., Inchausti, P., Lavorel, S., Lawton, J. H., Lodge, D. M., Loreau, M., Naeem, S., Schmid, B., Setala, H., Symstad, A. J., Vandermeer, J., and Wardle, D. A. (2005). Effects of biodiversity on ecosystem functioning: a consensus of current knowledge. Ecol. Monogr. 75, 3-35.

Horner-Devine, M. C., Lage, M., Hughes, J. B., and Bohannan, B. J. M. (2004). A taxa-area relationship for bacteria. Nature 432, 750-753.

Jehmlich, N., Schmidt, F., Taubert, M. Seifert, J., von Bergen, M., Richnow, H. H., and Vogt, C. (2009). Comparison of methods for simultaneous identification of bacterial species and determination of metabolic activity by protein-based stable isotope probing (protein-SIP) experiments. Rapid Commun. Mass Spectrom. 23, 1871-1878.

Jones, C. M., and Hallin, S. (2010). Ecological and evolutionary factors underlying global and local assembly of denitrifier communities. ISME J. 4 , 633-641.

Kalyuzhnaya, M. G., Beck, D. A. C., Suciu, D., Pozhitkov, A., Lidstrom, M. E., and Chistoserdova, L. (2010). Functioning in situ: gene expression in Methylotenera mobilis in its native environment as assessed through transcriptomics. ISME J. 4, 388-398.

Kato, S., and Watanabe, K. (2010). Ecological and evolutionary interactions in syntrophic Methanogenic consortia. Microbes Environ. 25, 145-151.

Kim, H. J., Boedicker, J. Q., Choi, J. W., and Ismagilov, R. F. (2008). Defined spatial structure stabilizes a synthetic multispecies bacterial community. Proc. Natl. Acad. Sci. U.S.A. 105, 18188-18193.

Koeppel, A., Perry, E. B., Sikorski, J., Krizanc, D., Warner, A., Ward, D. M., Rooney, A. P., Brambilla, E., Connor, N., Ratcliff, R. M., Nevo, E., and Cohan, F. M. (2008). Identifying the fundamental units of bacterial diversity: a paradigm shift to incorporate ecology into bacterial systematics. Proc. Natl. Acad. Sci. U.S.A. 105 2504-2509.

Konopka, A. (2009). What is microbial community ecology? ISME J. 3 , 1223-1230.
Konopka, M. C., Strovas, T. J., Ojala, D. S., Chistoserdova, L., Lidstrom, M. E., and Kalyuzhnaya, M. G. (2011). Respiration response imaging for realtime detection of microbial function at the single-cell level. Appl. Environ. Microbiol. 77, 67-72.

Konstantinidis, K. T., and Tiedje, J. M. (2005). Genomic insights that advance the species definition for prokaryotes. Proc. Natl. Acad. Sci. U.S.A. 102, 2567-2572.

Lauber, C. L., Hamady, M., Knight, R., and Fierer, N. (2009). Pyrosequencingbased assessment of soil $\mathrm{pH}$ as a predictor of soil bacterial community structure at the continental scale. Appl. Environ. Microbiol. 75, 5111-5120.

Leveau, J. H. J. (2009). Individual-based ecology of plant-associated bacteria. Phytopathology 99, S155-S155.

Lindow, S. E., and Leveau, J. H. (2002). Phyllosphere microbiology. Curr. Opin. Biotechnol. 13, 238-243.

Loreau, M., and Hector, A. (2001). Partitioning selection and complementarity in biodiversity experiments. Nature 412, 72-76.

McDaniel, L. D., Young, E., Delaney, J., Ruhnau, F., Ritchie, K. B., and Paul, J. H. (2010). High frequency of horizontal gene transfer in the oceans. Science 330, 50-50.

McGill, B. J., Enquist, B. J., Weiher, E., and Westoby, M. (2006). Rebuilding community ecology from functional traits. Trends Ecol. Evol. 21, 178-185.

Millennium Ecosystem Assessment. (2005). Ecosystems and Human Well-being: General Synthesis. United Nations. Available at: www.millenniumassessment.org/en/synthesis. aspx

Miyatake, T., MacGregor, B. J., and Boschker, H. T. S. (2009). Linking microbial community function to phylogeny of sulfate-reducing Deltaproteobacteria in marine sediments by combining stable isotope probing with magnetic-bead capture hybridization of $16 \mathrm{~S}$ rRNA. Appl. Environ. Microbiol. 75, 4927-4935.

Musat, N., Halm, H., Winterholler, B., Hoppe, P., Peduzzi, S., Hillion, F., Horreard, F., Amann, R., Jorgensen, B. B., and Kuypers, M. M. M. (2008). A single-cell view on the ecophysiology of anaerobic phototrophic bacteria. Proc. Natl. Acad. Sci. U.S.A. 105, 17861-17866.

Pace, N. R. (2009). Mapping the tree of life: progress and prospects. Microbiol. Mol. Biol. Rev. 73, 565-576.

Philippot, L., Andersson, S. G. E., Battin, T. J., Prosser, J. I., Schimel, J. P., Whitman, W. B., and Hallin, S. (2010). The ecological coherence of higher bacterial taxonomic ranks. Nat. Rev. Microbiol. $8,523-529$. 
Pommier, T., Canback, B., Riemann, L., Bostrom, K. H., Simu, K., Lundberg, P., Tunlid, A., and Hagstrom, A. (2007). Global patterns of diversity and community structure in marine bacterioplankton. Mol. Ecol. 16, 867-880.

Prosser, J. I., Bohannan, B. J. M., Curtis, T. P., Ellis, R. J., Firestone, M. K., Freckleton, R. P., Green, J. L., Green, L. E., Killham, K., Lennon, J.J., Osborn, A. M., Solan, M., van der Gast, C. J., and Young, J. P. W. (2007). Essay - the role of ecological theory in microbial ecology. Nat. Rev. Microbiol. 5, 384-392.

Raes, J., and Bork, P. (2008). Systems microbiology - timeline - molecular eco-systems biology: towards an understanding of community function. Nat. Rev. Microbiol. 6, 693-699.

Ranjard, L., Dequiedt, S., Jolivet, C., Saby, N. P. A., Thioulouse, J., Harmand, J., Loisel, P., Rapaport, A., Fall, S., Simonet, P., Joffre, R., Boure, N. C. P., Maron, P. A., Mougel, C., Martin, M. P., Toutain, B., Arrouays, D., and Lemanceau, P. (2010). Biogeography of soil microbial communities: a review and a description of the ongoing French national initiative. Agron. Sustain. Dev. 30, 359-365.

Rasche, F., Lueders, T., Schloter, M., Schaefer, S., Buegger, F., Gattinger, A., Hood-Nowotny, R. C., and Sessitsch, A. (2009). DNA-based stable isotope probing enables the identification of active bacterial endophytes in potatoes. New Phytol. 181, 802-807.

Roesch, L. F., Fulthorpe, R. R., Riva, A., Casella, G., Hadwin, A. K. M., Kent, A. D., Daroub, S. H., Camargo, F. A. O., Farmerie, W. G., and Triplett, E.W. (2007). Pyrosequencing enumerates and contrasts soil microbial diversity. ISME J. 1, 283-290.

Rusch, D. B., Halpern, A. L., Sutton, G., Heidelberg, K. B., Williamson, S., Yooseph, S., Wu, D. Y., Eisen, J. A., Hoffman, J.M., Remington, K., Beeson, K., Tran, B., Smith, H., Baden-Tillson, H., Stewart, C., Thorpe, J., Freeman,
J., Andrews-Pfannkoch, C., Venter, J. E., Li, K., Kravitz, S., Heidelberg, J. F., Utterback, T., Rogers, Y.H., Falcon, L. I., Souza, V., Bonilla-Rosso, G., Eguiarte, L. E., Karl, D. M., Sathyendranath, S., Platt, T., Bermingham, E., Gallardo, V., Tamayo-Castillo, G., Ferrari, M. R., Strausberg, R. L., Nealson, K., Friedman, R., Frazier, M., and Venter, J. C. (2007). The sorcerer II global ocean sampling expedition: northwest Atlantic through eastern tropical Pacific. PLoS Biol. 5, 398-431. doi: 10.1371/journal.pbio.0050077

Rutgers, M., Schouten, A. J., Bloem, J., van Eekeren, N., de Goede, R. G. M., Akkerhuis, G., van der Wal, A., Mulder, C., Brussaard, L., and Breure, A. M. (2009). Biological measurements in a nationwide soil monitoring network. Eur. J. Soil Sci. 60, 820-832.

Salles, J. F., Poly, F., Schmid, B., and Le Roux, X. (2009). Community niche predicts the functioning of denitrifying bacterial assemblages. Ecology 90 , 3324-3332.

Schleifer, K. H. (2009). Classification of bacteria and archaea: past, present and future. Syst. Appl. Microbiol. 32, 533-542.

Setala, H., and McLean, M. A. (2004). Decomposition rate of organic substrates in relation to the species diversity of soil saprophytic fungi. Oecologia 139, 98-107.

Sogin, M. L., Morrison, H. G., Huber, J. A., Mark Welch, D., Huse, S. M., Neal, P. R., Arrieta, J. M., and Herndl, G. J. (2006). Microbial diversity in the deep sea and the underexplored "rare biosphere”. Proc. Natl. Acad. Sci. U.S.A. 103, 12115-12120.

Staley, J. T. (2006). The bacterial species dilemma and the genomic-phylogenetic species concept. Philos. Trans. $R$. Soc. B Biol. Sci. 361, 1899-1909.

Sutherland, W. J., Clout, M., Cote, I. M., Daszak, P., Depledge, M. H., Fellman, L., Fleishman, E., Garthwaite, R., Gibbons, D. W., De Lurio, J., Impey, A. J., Lickorish, F., Lindenmayer,
D., Madgwick, J., Margerison, C., Maynard, T., Peck, L. S., Pretty, J., Prior, S., Redford, K. H., Scharlemann, J. P. W., Spalding, M., and Watkinson, A. R. (2010). A horizon scan of global conservation issues for 2010. Trends Ecol. Evol. (Amst.) 25, 1-7.

Tamames, J., Abellan, J. J., Pignatelli, M., Camacho, A., and Moya, A. (2010). Environmental distribution of prokaryotic taxa. BMC Microbiol. 10, 85. doi: 10.1186/1471-2180-10-85 van der Heijden, M. G. A., Bardgett, R. D., and van Straalen, N. M. (2008). The unseen majority: soil microbes as drivers of plant diversity and productivity in terrestrial ecosystems. Ecol. Lett. 11, 296-310.

Verstraete, W., Wittelbolle, L., Heylen, K., Vanparys, B., de Vos, P., van de Wiele, T., and Boon, N. (2007). Microbial resource management: the road to go for environmental biotechnology. Eng. Life Sci. 7, 117-126.

von Mering, C., Hugenholtz, P., Raes, J., Tringe, S. G., Doerks, T., Jensen, L. J., Ward, N., and Bork, P. (2007). Quantitative phylogenetic assessment of microbial communities in diverse environments. Science 315, 1126-1130.

Wagner, M. (2009). Single-cell ecophysiology of microbes as revealed by Raman microspectroscopy or secondary ion mass spectrometry imaging. Annu. Rev. Microbiol. 63, 411-429.

Whiteley, A. S., Manefield, M., and Lueders, T. (2006). Unlocking the "microbial black box" using RNAbased stable isotope probing technologies. Curr. Opin. Biotechnol. 17, 67-71.

Whitman, W. B., Coleman, D. C., and Wiebe, W. J. (1998). Prokaryotes: the unseen majority. Proc. Natl. Acad. Sci. U.S.A. 95, 6578-6583.

Wilmes, P., and Bond, P. L. (2009). Microbial community proteomics: elucidating the catalysts and metabolic mechanisms that drive the earth's biogeochemical cycles. Curr. Opin. Microbiol. 12, 310-317.
Wittebolle, L., Marzorati, M., Clement, L., Balloi, A., Daffonchio, D., Heylen, K., De Vos, P., Verstraete, W., and Boon, N. (2009). Initial community evenness favours functionality under selective stress. Nature 458, 623-626.

Wohl, D. L., Arora, S., and Gladstone, J. R. (2004). Functional redundancy supports biodiversity and ecosystem function in a closed and constant environment. Ecology 85, 1534-1540.

Woyke, T., Tighe, D., Mavromatis, K., Clum, A., Copeland, A., Schackwitz, W., Lapidus,A., Wu, D.Y., McCutcheon, J. P., McDonald, B. R., Moran, N. A., Bristow, J., and Cheng, J.F. (2010). One bacterial cell, one complete genome. PLoS ONE 5, e10314. doi: 10.1371/ journal.pone.0010314

Zhou, J. Z., Deng, Y., Luo, F., He, Z. L., Tu, Q. C., and Zhi, X. Y. (2010). Functional molecular ecological networks. MBio 1, e00169-10.

Zhou, J. Z., Kang, S., Schadt, C. W., and Garten, C. T. (2008). Spatial scaling of functional gene diversity across various microbial taxa. Proc. Natl. Acad. Sci. U.S.A. 105, 7768-7773.

Conflict of Interest Statement: The author declares that the research was conducted in the absence of any commercial or financial relationships that could be construed as a potential conflict of interest.

Received: 13 December 2010; accepted: 05 April 2011; published online: 25 April 2011. Citation: Bodelier PLE (2011) Toward understanding, managing, and protecting microbialecosystems. Front. Microbio. 2:80. doi: 10.3389/fmicb.2011.00080

This article was submitted to Frontiers in Terrestrial Microbiology, a specialty of Frontiers in Microbiology. Copyright $\odot 2011$ Bodelier. This is an openaccess article subject to a non-exclusive license between the authors and Frontiers Media $S A$, which permits use, distribution and reproduction in other forums, provided the original authors and source are credited and other Frontiers conditions are complied with. 